\title{
CAMBRIDGE
}

GREAT MINDS COME FROM GREAT BOOKS

\section{A Population History of the United States}

Second Edition

Herbert S. Klein

\$94.00: HB: 978-1-107-01598-2 \$32.99: PB: 978-1-107-61362-1: $295 \mathrm{pp}$.

\section{A Short History of} Ireland

Third Edition

John O'Beirne Ranelagh \$83.00: HB: 978-1-107-00923-3 \$28.99: PB: 978-1-107-40194-5: $445 \mathrm{pp}$.

\section{Classified}

Secrecy and the State in Modern Britain

Christopher Moran

\$39.99: HB: 978-1-107-00099-5: $449 \mathrm{pp}$.

\section{Evaluating Empire} and Confronting Colonialism in Eighteenth-Century Britain

Jack P. Greene

\$85.00: HB: 978-1-107-03055-8 \$29.99: PB: 978-1-107-68298-6 $404 \mathrm{pp}$.
Fighting

the Mau Mau

The British Army and

Counter-Insurgency in the

Kenya Emergency

Huw Bennett

Cambridge Military

Histories

\$85.00: HB: 978-1-107-02970-5 \$29.99: PB: 978-1-107-65624-6: $317 \mathrm{pp}$.

Free Trade and Sailors' Rights in the War of 1812

Paul A. Gilje

\$85.00: HB: 978-1-107-02508-0 \$29.99: PB: 978-1-107-60782-8. $438 \mathrm{pp}$.

\section{Manifold Mirrors}

The Crossing Paths of the Arts and Mathematics Felipe Cucker

\$90.00: HB: 978-0-521-42963-4 \$29.99: PB: 978-0-521-72876-8: $424 \mathrm{pp}$.

\section{Richard Bancroft} and Elizabethan Anti-Puritanism Patrick Collinson

Cambridge Studies in Early Modern British History

\$75.00: HB: 978-1-107-02334-5: $247 \mathrm{pp}$.

\section{The Dynamiters}

Irish Nationalism and Political Violence in the Wider World, 1867-1900

Niall Whelehan

\$103.00: HB: 978-1-107-02332-1: $340 \mathrm{pp}$.

\section{The Look of the Past}

Visual and Material Evidence in Historical Practice

Ludmilla Jordanova

\$103.00: HB: 978-0-521-88242-2 \$42.00: PB: 978-0-521-70906-4 $264 \mathrm{pp}$.

\section{Who's Bigger?}

Where Historical Figures Really Rank

Steven Skiena and Charles Ward

\$27.99: HB: 978-1-107-04137-0. $391 \mathrm{pp}$.

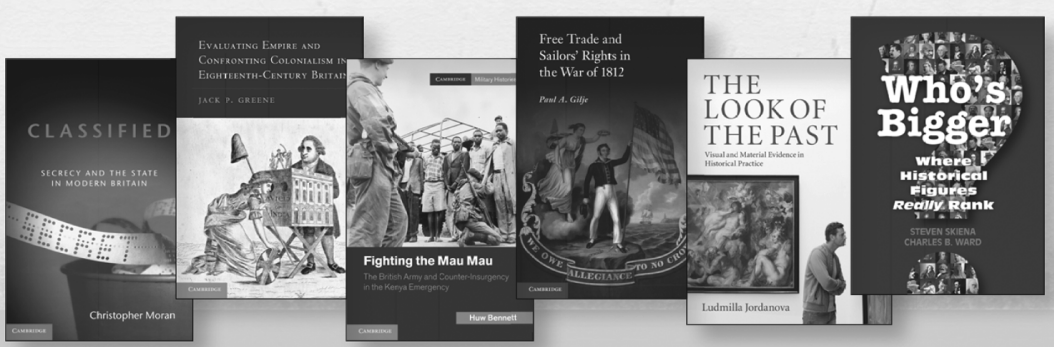

Prices subject to change. 


\section{CAMBRIDGE}

\section{GREAT MINDS COME FROM GREAT BOOKS}

\section{The First Knowledge Economy}

Human Capital and the

European Economy, 1750-1850

Margaret C. Jacob

\$85.00: HB: 978-1-107-04401-2

\$29.99: PB: 978-1-107-61983-8:

$268 \mathrm{pp}$.

\section{A Concise History of Brazil, 2nd Edition}

Boris Fausto

With contributions by

Sergio Fausto

Cambridge Concise Histories

\$90.00: HB: 978-1-107-03620-8

\$28.99: PB: 978-1-107-63524-1

$400 \mathrm{pp}$

\section{A Concise History of Switzerland}

Clive H. Church

and Randolph C. Head

Cambridge Concise Histories

\$80.00: HB: 978-0-521-19444-0

\$27.99: PB: 978-0-521-14382-0:

$339 \mathrm{pp}$.

\section{A History of Zimbabwe}

Alois S. Mlambo

\$80.00: HB: 978-1-107-02170-9

\$27.99: PB: 978-1-107-68479-9:

$304 \mathrm{pp}$.
Colonization and

the Origins of

Humanitarian

Governance

Protecting Aborigines across

the Nineteenth-Century

British Empire

Alan Lester

and Fae Dussart

Critical Perspectives on Empire \$99.00: HB: 978-1-107-00783-3: $320 \mathrm{pp}$.

\section{Compromise}

A Political and

Philosophical History

Alin Fumurescu

\$90.00: HB: 978-1-107-02943-9:

$305 \mathrm{pp}$.

Now in Paperback!

Cross-Cultural

Exchange in the

Atlantic World

Angola and Brazil during the

Era of the Slave Trade

Roquinaldo Ferreira

African Studies

\$27.99: PB: 978-1-107-67144-7:

$282 \mathrm{pp}$.
Encountering

the Pacific in

the Age of the

Enlightenment

John Gascoigne

\$120.00: HB: 978-0-521-87959-0.

$574 \mathrm{pp}$.

\section{European Colonialism} since 1700

James R. Lehning

New Approaches to European

History

\$80.00: HB: 978-0-521-51870-3

\$27.99: PB: 978-0-521-74171-2

$320 \mathrm{pp}$.

Mill and

Paternalism

Gregory Claeys

\$95.00: HB: 978-0-521-76108-6: $262 \mathrm{pp}$.

The Moral Economy

Poverty, Credit, and Trust in Early Modern Europe

Laurence Fontaine

\$90.00: HB: 978-1-107-01881-5

\$34.99: PB: 978-1-107-60370-7

$326 \mathrm{pp}$.

Prices subject to change.

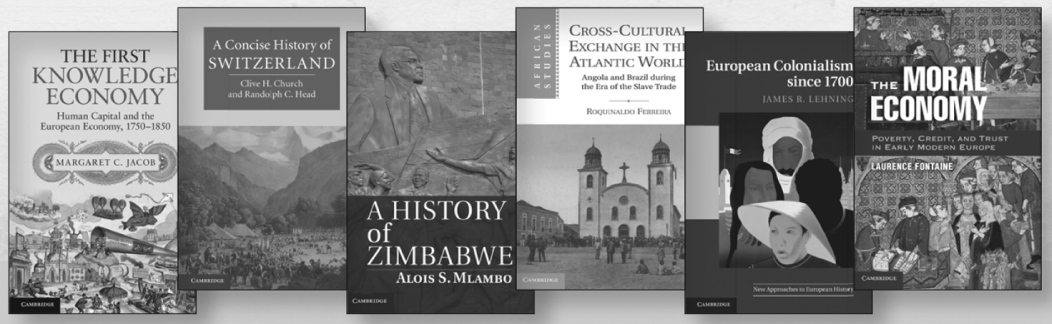

www.cambridge.org 


\section{Central European History}

Published for the Conference Group for Central European History of the American Historical Association

\section{Editor-in-Chief}

Kenneth Ledford, Case Western Reserve University, USA Associate Editor (Book Reviews)

Catherine Epstein, Amherst College, USA

Central European History offers articles, review essays, and book reviews that range widely through the history of Germany, Austria, and other German-speaking regions of Central Europe from the medieval era to the present. All topics and approaches to history are welcome, whether cultural, social, political, diplomatic, intellectual, economic, and military history, as well as historiography and methodology. Contributions that treat new fields, such as post-1945 and post-1989 history, maturing fields such as gender history, and less-represented fields such as medieval history and the history of the Habsburg lands are especially desired. The journal thus aims to be the primary venue for scholarly exchange and debate among scholars of the history of Central Europe.

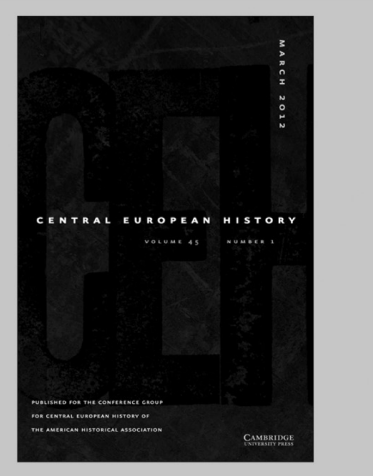

Central European History is available online at: http://journals.cambridge.org/ccc

To subscribe contact Customer Services

in Cambridge:

Phone +44 (0)1223 326070

$\mathrm{Fax}+44(0) 1223325150$

Email journals@cambridge.org

\section{in New York:}

Phone +1 (845) 3537500

$\mathrm{Fax}+1$ (845) 3534141

Email

subscriptions_newyork@cambridge.org

\section{Free email alerts}

Keep up-to-date with new material - sign up at

journals.cambridge.org/register 
This journal is registered with the Copyright Clearance Center, 222 Rosewood Drive, Danvers, MA oI923, USA. Organizations in the USA who are also registered with the C.C.C. may therefore copy material (beyond the limits permitted by sections Io7 and Io8 of US Copyright law) subject to payment to G.C.C. of the per copy fee of \$12.oo. This consent does not extend to multiple copying for promotional or commercial purposes. Code oor8-246x/I4 \$I2.00. ISI Tear Sheet Service, 350 I Market Street, Philadelphia, PA I9IO4, USA, is authorized to supply single copies of separate articles for private use only. Organizations authorized by the Copyright Licensing Agency may also copy material subject to the usual conditions. For all other use, permission should be sought from Cambridge University Press.

\section{INSTRUGTIONS FOR GONTRIBUTORS}

I The Historical fournal publishes articles on all aspects of history since the fifteenth century.

2 All contributions, correspondence, and books for review should be sent to: The Editors, The Historical Fournal, Faculty of History, West Road, Cambridge CB3 9EF. The e-mail address is hj@hist.cam.ac.uk. Fax: +(0) 1223 335968. Please mark faxes "for editors of Historical Journal". Tel No: +44(0) 1223335347.

3 Articles should not exceed 10,000 words and Communications 5,000 words in length. Historiographical reviews should not exceed 8,000 words. Contributions must follow the layout and stylistic conventions of The Historical fournal. Detailed Instructions for Contributors should be consulted at http://journals.cambridge.org/his

4 Three paper copies of all submissions (articles, communications, review articles, historiographical reviews, single reviews) should initially be submitted. Two of the copies should be anonymous. Receipt of submissions will be acknowledged by email; and authors will then usually be asked to submit an electronic copy as an email attachment.

5 Submission of material will be taken to attest that it is unpublished (even in a language other than English) and is not at present being considered for publication elsewhere. Upon acceptance of a paper, the author will be asked to assign copyright (on certain conditions) to Cambridge University Press.

6 The Journal is willing to consider unpublished articles submitted in languages other than English, and in such cases a short resumé (max. one page) in English should accompany the submission. Financial assistance may be offered by the Journal towards the costs of translation into English.

7 Figures must be submitted electronically, scanned at a minimum of 320 dpi and saved as either TIFF or EPS files; if you wish to compress them, use lossless compression software such as the LZW compression package. Illustrative material should be numbered as part of a sequence of figures. Figure captions are to be supplied on a separate sheet.

8 Contributors are responsible for obtaining permissions to reproduce all material for which they do not hold copyright for worldwide publication in all forms and media, including electronic publication, and for ensuring that the appropriate acknowledgements are included.

9 The Editors endeavour to provide a decision on contributions within three months, and thereafter to publish those accepted within eighteen months. They reserve the right to change publication date at short notice, owing to space constraints and the need to achieve balance of content.

This journal issue has been printed on FSC-certified paper and cover board. FSC is an independent, non-governmental, not-for-profit organization established to promote the responsible management of the world's forests. Please see www.fsc.org for information.

(C) Cambridge University Press 2014

\section{CAMBRIDGE UNIVERSITY PRESS}

The Edinburgh Building, Cambridge CB2 8RU, United Kingdom

32 Avenue of the Americas, New York, NY Ioor3-2473, USA

477 Williamstown Road, Port Melbourne, VIC 3207 , Australia

Ruiz de Alarcón I3, 280I4 Madrid, Spain

Dock House, The Waterfront, Cape Town 8oor, South Africa 


\section{THE HISTORICAL JOURNAL}

\section{CONTENTS}

\section{ARTICLES}

Alan S. Ross Pupils' choices and social mobility after the Thirty Years War:

a quantitative study

JORDAN S. Downs The curse of Meroz and the English Civil War

GABY MAHLBERG Les juges jugez, se justifiants (1663) and Edmund Ludlow's

Protestant network in seventeenth-century Switzerland

MATTHEW Neufeld Parliament and some roots of whistle blowing during the

Nine Years War

DANIEL RITCHIE Abolitionism and evangelicalism: Isaac Nelson, the Evangelical Alliance, and the transatlantic debate over Christian fellowship with slaveholders

MARK HEWITSON On war and peace: German conceptions of conflict, 1792-1815

MARTHA VANDREI A Victorian invention? Thomas Thornycroft's 'Boadicea group' and the idea of historical culture in Britain

TOMÁs IRISH Fractured families: educated elites in Britain and France and the challenge of the Great War

Historiographical REVIEW

AlEXIs D. LiTVINE The industrious revolution, the industriousness discourse, and the development of modern economies

Review Article

GEOFFREY PLANK Protestantism in a multi-cultural early America

\section{CORRIGENDUM}

SAMANTHA A. SHAVE The impact of Sturges Bourne's poor law reforms in rural England - CORRIGENDUM

\section{Cambridge Journals Online}

For further information about this journal please go to the journal website at: journals.cambridge.org/his

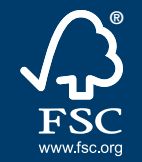

MIX

Paper from responsible sources FSC ${ }^{\oplus}$ C007785
CAMBRIDGE UNIVERSITY PRESS 